\title{
sciendo MODELLING SAFETY CULTURE AMONG CREWS OF SEAFARING VESSELS
}

DOI 10.2478/ntpe-2018-0012

\author{
Assoc. Prof. PhD. Andrzej Adamkiewicz \\ Maritime University of Szczecin, Poland \\ PhD. Agata Krystosik-Gromadzińska \\ West Pomeranian University of Technology, Poland
}

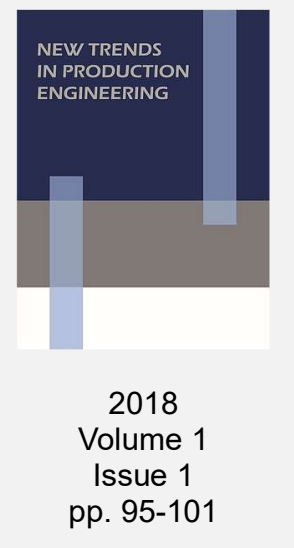

\begin{abstract}
Marine work conditions, differing from those on land, have been presented. The study has identified a multitude of factors generating physical and psychical effects on crew members, different cultural patterns and dangers which have to be overcome to reach the state when thinking of safety accompanies all performed activities. Creation of legislature and procedures and their observance have been presented as a basis for constructing safety culture and the sense of safety. Safety management, coordinated by ship owners, has been justified as activities to be realized on ships. It has been indicated in this study that building up safety culture among the members of the power plant crew of seafaring ships is the most important issue due to the fact that their work environment is unfriendly to humans and that there is a high fire risk in a ship power plant.
\end{abstract}

Keywords: safety, seafaring ship, management, crew, fire

\section{INTRODUCTION INTO THE KNOWLEDGE ON WORK SAFETY ON SHIPS}

Work at sea significantly differs from that performed on land. Its rhythm and conditions are different. The ship has to reach a designated place safely and it has to be done at a designated time. Requirements are precisely defined just as acting procedures. However, emergency or disastrous situations, far different from regular patterns, may happen. Then the crew must rely on their experience, knowledge and training. Solving operational problems often requires nonstandard action. The ability to act not only in stable everyday conditions, but in situations when the crew is under stress, maintaining safety culture standards is a difficult task. Pressure of time, danger, ship owner's strong wishes - all of these factors may cause that the crew does not stick to procedures whose observance should be something natural as safety should always be the priority.

Building up safety culture among the staff employed on seafaring ships, which was previously overlooked, is becoming a better and better understood and appreciated problem. It is a lengthy but profitable process as an appropriate approach to safety does not generate costs but lowers them. A discussion is going on among ship owners, in international bodies that are responsible for making and enforcing law as well as among academics. The issue of safety culture has been dealt with by Arslan (Arslan, et al., 2016), Havold (Havold and Nesset, 2009) and Veiga (Veiga, 2002), and the matter of human factor in safety management in water transport has been approached by among others Havold (Havold, 2007), Hetherington (Hetherington, et al., 2006), Hystad (Hystad, et al., 2017), Berg (Berg, 2013) and Gausdal (Gausdal and Makarova, 2017). Culture of safe operation on ships has been studied on different kinds of vessels (Ek, 2014), offshore units on the Norwegian Sea among others in the context of crew errors (Rumawas and Asbjornslett, 2016) and on Greek coastal ships (Gemelos and Ventikos, 2008).

The role of leader in safety building process has been described in publications (Bielic, et al., 2017; Borgersen, et al., 2014; Kim and Gausdal, 2017; Lu, et al., 2016).

Safety management as an element of safety culture was undertaken in the works (Hanchrow, 2017; Kongsvik, et al., 2014; Wang, 2002). 
As a result of analyses it was indicated that due to the number of errors made by crews, more attention should be paid to the influence of human factor on operational safety and an effort should be made to improve its elimination throughout modelling safety culture.

\section{THE ROLE OF CLASSIFICATION SOCIETIES AND INTERNATIONAL MARITIME ORGANISATIONS IN SHIP SAFETY MANAGEMENT}

Classification societies get engaged in promoting safety culture directing crew activities to improve the quality of equipment servicing. Class NK, American Bureau of Shipping (ABS) publish papers on rules of good equipment servicing on ships (ClassNK, 2015; ABS, 2009). Among others they contain check lists which describe procedures, sequences of activities to be performed and give references to regulation requirements.

The issue of work conditions on ships, crew safety, safety culture are analysed by International Maritime Organisation and International Labour Organisation (ILO). Conventions and other documents published by these organisations determined with small differences, among others permissible number of working hours and minimal resting time as well as requirements regarding place of resting. The problem of bad working conditions is mainly valid in the case of multinational ship crews of ship owners employing sailors with lowest training and payment.

Good safety management is an element of safety culture construction is which is realized by both the activities undertaken during operation and planning as well as execution of emergency trainings. It is carried out in compliance with requirements of national and international regulations. Simulators are also used for staff training.

Unlucky occurrences and accidents on ships are, however, a part of their operation and they are either caused by humans or by technical factors. We can only wonder at the accepted level of risk in sailing and methods of controlling it and also on the influence of building up safety culture among crews as a way to decrease the risk.

\section{DEFINITIONS OF TERMS FOR THE NEEDS OF SAFETY CULTURE PHILOSOPHY}

To define the term of safety culture considered in the context of work on board of a ship, it is necessary to define five basic terms such as safety, safety management, technical safety and ship safety.

Safety is understood very broadly. Informally it is defined as a state of feeling safe when there is no expectation of emergency or fault occurrence (Pihowicz, 2008). It is a basic need of a human being and in reference to technology, it is an indicator of the ability of a system to function correctly.

Technical safety is understood as the ability of a given technical object, operating in defined conditions, to ensure within expected limits and during a certain time that there will be no danger for people and the environment.

In quantitative approach, technical safety is the probability that there will be no danger for people or the environment in defined conditions, during a certain time and within expected limits (Pihowicz, 2008). Technical safety is also defined indirectly throughout durability between emergencies, probability of technical danger, frequency of technical emergencies, intensity of emergencies, the expected value of durability between emergencies, technical safety coefficient, total time of being out of action, probability of technical safety restoration, frequency of technical safety restoration, intensity of technical safety restoration, the expected value of the total time of being out of action as a result of faults causing technical danger, availability of technical safety i.e. protection quality (Pihowicz, 2008).

It is suggested that ship safety should be understood as the ability of a system (ship and man) operating in definite conditions (in a definite operational state, at definite sailing conditions, assuming usability of the vessel and lack of danger from other ships or people) to ensure within definite limits (with the acceptance of a chance that incidents insignificant for the voyage might occur, which, however, will not break up the voyage and are not dangerous) and during a defined time (expected operational time, or the time until the next class overhaul or servicing) there will be no danger for people and the environment (for passengers, crew members or marine environment). Due to a multitude of factors influencing ship safety, it will not be, however, a 
thorough definition as in today's understanding ship safety is an interdisciplinary term whose correct definition requires not only technical knowledge on ship operational safety as a technical object but also the knowledge of navigation, workplace ergonomics, work psychology, international politics, metrology, hydrology, legislature, issues connected with terrorism and others. Ship safety is connected with its technical condition, equipment, cargo, crew training and experience, with the necessity to comply with international regulations, dedication and sense. Safety also means taking care of the ship technical codition and its correct operation. It can be considered throughout the evaluation of correct operation of machanisms and equipment but also throughout correct operation of people or the influence of hydrometeorological conditions. The state of safety is not a stable one. In order to ensure its stability, a safety management system is set up.

Safety management is understood as a set of recommendations and operation procedures as well as created tools whose task is to improve crew operations to eliminate human errors.

Bulding safety culture on seafarers requires good understanding of relations between crew members, crew members and technical objects, technical objects and influence of hydrometeorological conditions which affect both components: the crew and the technical object. Safety culture in will be understood as a set of qualities and attitudes of people. It is the result of individual and group values, qualities, remarks, competences and behaviour patterns as well as the style and quality of safety management in an organization. Fig 1 presents consecutive stages of safety culture building for a single person - a crew member.

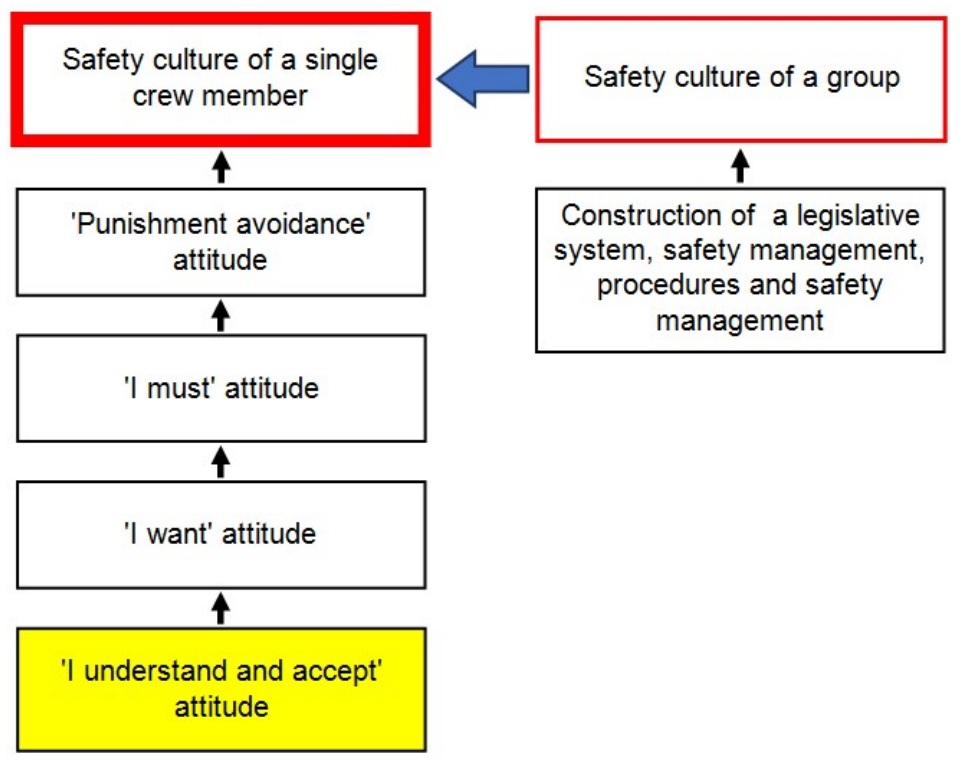

Fig. 1. Procedure of constructing safety culture of a single crew member

The aim of building safety culture is to form and modify behaviours, convictions and attitudes of employees in such a way that they would become responsible for their own safety and the safety of their co-workers and technical objects.

\section{INFLUENCE OF HUMAN FACTOR ON THE CHANCE OF RISK OCCURRANCE ON A CHOSEN EXAMPLE}

Most accidents which take place on a ship are the result of intentional or unintentional crew activities. The most serious emergency on a ship is fire in the ship engine room. Fig. 2, using the Ishikawa diagram, presents a graphic representation of qualitative analysis of factors favouring occurrence of fire in a ship engine room.

The diagram was constructed for nine main categories of causes. Due to their large number in particular categories, they were marked by numbers basing on the rule that those of higher significance were placed closer to the centre of the body. The description of categories referring to the human factor are shown in tables 1-5. 


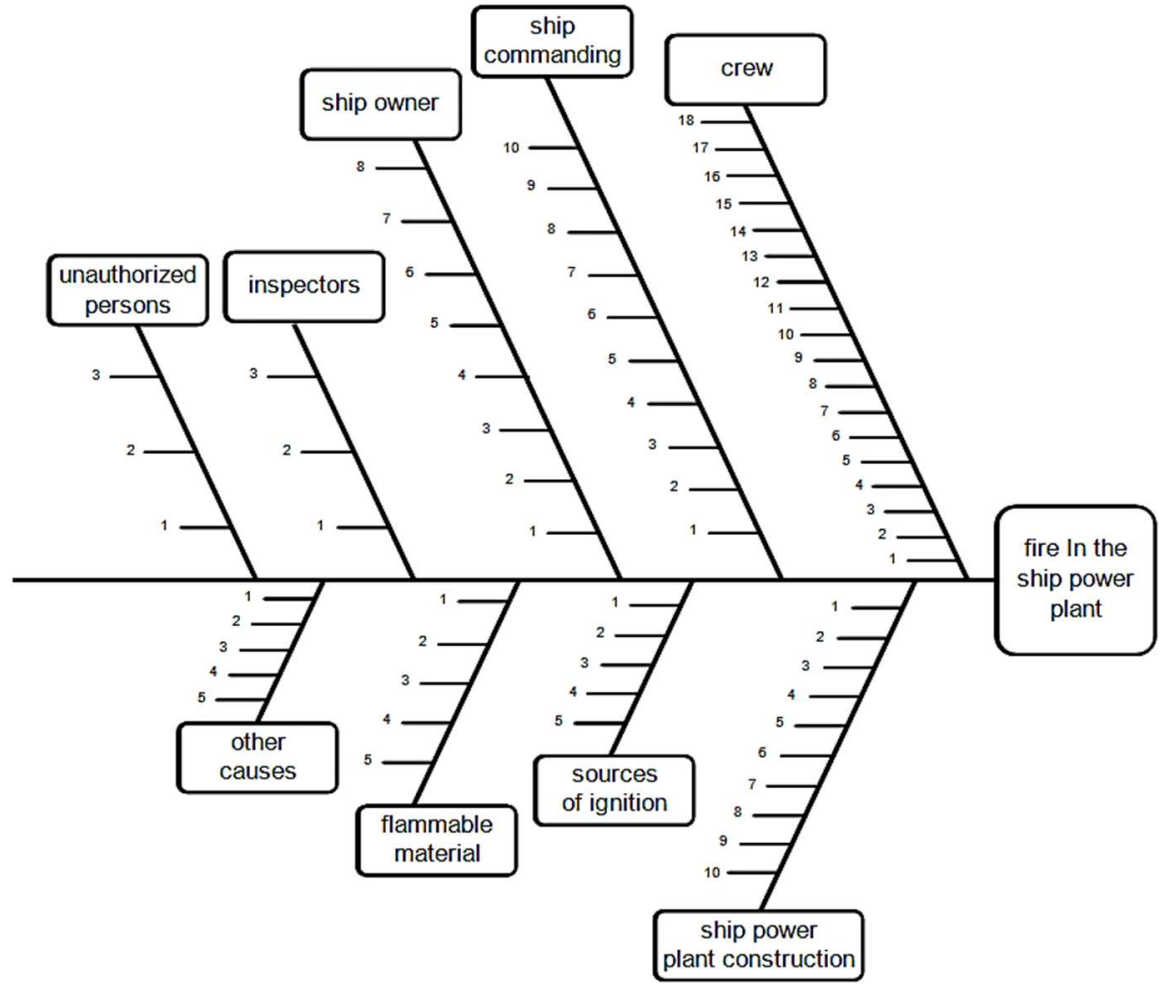

Fig. 2. Basic causes of fire occurring in a ship engine room determined using the Ishikawa diagram method

Table 1

Basic causes of the (engine room) crew category

\begin{tabular}{|c|l|}
\hline No & \multicolumn{1}{|c|}{ Basic cause } \\
\hline 1. & Insufficient knowledge and experience \\
\hline 2. & Insufficient knowledge of regulations and procedures \\
\hline 3. & Non-observance of regulations and procedures \\
\hline 4. & Lack of understanding of risk and not expecting consequences \\
\hline 5. & Bad work organisation \\
\hline 6. & Lack of mock alarms at sea and trainings and education on land \\
\hline 7. & Usage of impermissible technical and organisational solutions \\
\hline 8. & Incorrect regulation of operational parameters of equipment \\
\hline 9. & Lack of supervision and control \\
\hline 10. & Non-observance of rules of operational strategy \\
\hline 11. & Insufficient attention to cleanliness \\
\hline 12. & Usage of inappropiate operational materials \\
\hline 13. & Bad psychical and physical condition of the crew \\
\hline 14. & Language barrier \\
\hline 15. & Insubordination, carelessness and negligence of responsibilities \\
\hline 16. & Overtiredness and exhaustion \\
\hline 17. & Over-age \\
\hline 18. & Addiction to some beverages \\
\hline
\end{tabular}

Table 2

Basic causes of Ship command category

\begin{tabular}{|c|l|}
\hline No & \multicolumn{1}{|c|}{ Basic cause } \\
\hline 1. & Insufficient knowledge and experience as well as routine \\
\hline 2. & Non-observance of regulations \\
\hline 3. & Unawareness of regulations \\
\hline 4. & Negligence and slugishness \\
\hline 5. & Lack of empathy and communication with the crew \\
\hline 6. & Negligence of alarms and bulletins \\
\hline 7. & Lack of authority and enforcement of orders \\
\hline 8. & Bad work organisation \\
\hline 9. & Lack of mock alarms \\
\hline 10. & Addiction to some beverages \\
\hline
\end{tabular}


Table 3

Basic causes of the Ship owner category

\begin{tabular}{|c|l|}
\hline No & \multicolumn{1}{|c|}{ Basic cause } \\
\hline 1. & Insufficient knowledge and experience \\
\hline 2. & Non-observance of regulations \\
\hline 3. & Insufficient knowledge of regulations \\
\hline 3. & Lack of finances \\
\hline 4. & Non-observance of operational strategy rules \\
\hline 5. & Not executing inspectors' recommendations \\
\hline 6. & Lack of duty execution \\
\hline 7. & Overdeveloped administration and incorrect division of duties \\
\hline 8. & Lack of correct information flow \\
\hline
\end{tabular}

Table 4

Basic causes of Inspectors category

\begin{tabular}{|c|l|}
\hline No & \multicolumn{1}{|c|}{ Basic cause } \\
\hline 1. & Insufficient knowledge of regulations and procedures \\
\hline 2. & Not thorough servicing \\
\hline 3. & Intentional no revealment of faults \\
\hline
\end{tabular}

Table 5.

Basic causes of Unauthorised persons category

\begin{tabular}{|c|c|}
\hline No & \multicolumn{1}{|c|}{ Basic cause } \\
\hline 1. & Other ships and marine objects \\
\hline 2. & Acts of terror and war activities \\
\hline 3. & Illegal immigrants, passengers \\
\hline
\end{tabular}

An analyse of the diagram and basic causes in particular categories allows to draw the conclusion that fires in a ship engine room are to a significant extent connected with crew, especially the engine crew, activities but also with ship command. Human errors, thus safety culture at an insufficient level, are the main causes of danger.

\section{BUILDING SAFETY CULTURE ON SHIPS}

Building safety culture requires activities which will equip crew members in correct attitudes and beliefs and first of all understanding of the problem. Acceptance and assimilation of the attitude where safety, both one's own and other crew members' as well as that of technical objects, is a priority will allow to carry on all activities in such a way that the level of safety will be acceptable. Being convinced of co-responsibility for safety will be the basis of unacceptance in oneself and others attitudes and activities which may jeopardize safety.

Building safety culture will benefit from correct safety management i.e. making regulations, procedures of activities and communication, tools supporting everyday machine servicing, mechanisms for motivating crew members, trainings on land and ships.

\section{SUMMARY}

The aim of safety culture building managers should be to develop among the crew a habit of constant thinking of safety which is to be a priority in all their activities. To a higher or lower extent most accidents can be predicted. There is, however, a high probability that they will not happen when each activity is accompanied by thinking of safety as a priority. It will be difficult but profitable to motivate crew members to thinking in such a way which will come from their inner conviction, attitude.

An important element of building safety culture on a ship is for the command to ensure good atmosphere in human relationships. Excessive stress resulting from bad relations may lead to occurrence of rebellious attitudes towards supervisors and isolation of particular crew members. It results in lack of cooperation possibilities which influence work quality and ship safety.

In a ship engine room, due to many factors causing danger and due to physical and psychical overload, building safety culture is of particular importance. Correct habits and attitudes in a significant way may assist in limiting the most dangerous incidents like fires. 
Assuming that decreasing the number of mistakes which result in accidents is one of the indicators of the level of safety culture then limitation of undesirable events including fires will be an achievement. It will be considered a success when constant crew supervision, punishments and reprimands turn out unnecessary while being sure that crew members feel coresponsible for their own safety and that of others. It is specially true for ship crews. In a majority of accidents the crews have to rely on themselves. During a fire they take up its extinguishing, trained officers supply medical help, the crew fights to prevent the ship from sinking and when no action is possible anymore they make the decision to leave the vessel. Mutual trust and actions for safety also in extreme situations will decide of the the chances of survival.

\section{REFERENCES}

ABS, (2009). Onboard Routine Maintenance Check Sheet. Available at: https://ww2.eagle.org/content/dam/eagle/publications/referencereport/Maintenance_checklist.pdf [Accessed 2 Sep. 2018].

Arslan, V., Kurt, R.E. and Turan, O. et al. (2016). Safety culture assessment and implementation framework to enhance maritime safety. In: 6th Transport Research Arena (TRA), Warsaw: Transportation Research Procedia, 14, pp. 3895-3904.

Berg, H.P. (2013). Human Factors and Safety Culture in Maritime Safety. International Journal on Marine Navigation and Safety of Sea Transportation, 7(3), pp. 343-352.

Bielic, T., Predovan, D. and Culin, J. (2017). The Role of the Master in Improving Safety Culture Onboard Ships. Transnav - International Journal on Marine Navigation and Safety of Sea Transportation, 11(1), pp.121-124.

Borgersen, H., C., Hystad, S. W., Larsson, G. et al. (2014). Authentic Leadership and Safety Climate Among Seafarers. Journal of Leadership\&Organizational Studies, 21(4), pp.394402.

ClassNK, (2017). Good Maintance on bard ships. Maintenance Checklist for the Master. Available https://www.classnk.or.jp/hp/pdf/info_service/psc/good_maintenance_on_board_ships_e2 017.pdf [Accessed 5 Aug. 2018].

Ek, A., Runefors, M. and Borell, J. (2014). Relationship between safety culture aspects - A work process to enable interpretation. Marine Policy, 44(2014), pp. 179-186.

Gausdal, A., H. and Makarova, J. (2017). Trust and safety onboard. WMU Journal of Maritime Affairs. 16(2), pp. 197-217.

Gemelos, I., C. and Ventikos, N., P. (2008). Safety in Greek Coastal Shipping: The Role and Risk of Human Factor Revisited. WMU Journal of Maritime Affairs, 7(1), pp. 31-49.

Hanchrow, G. A. (2017). International Safety Management - Safety Management Systems and the Challenges of Changing a Culture. Transnav - International Journal on Maritime Navigation and Safety of Sea Transportation, 11(1), pp. 125-131.

Havold, J., I. and Nesset, E. (2009). From safety culture to safety orientation: Validation and simplification of a safety orientation scale using a sample of seafarers working for Norwegian ship owners. Safety Science, 47(3), pp. 305-326.

Havold, J.,I. (2007). National cultures and safety orientation: A study of seafarers working for Norwegian shipping companies. Work and Stress, 21 (2), pp. 173-195.

Hetherington, C., Flin, R. and Mearns, K. (2006). Safety in shipping: The human element. Journal of Safety Research, 37(4), pp. 401-411.

Hystad, S.W., Nielsen, M.B., and Eid, J. (2017). The impact of sleep quality, fatigue and safety climate on the perceptions of accident risk among seafarers. European Review of Applied Psychology - Revue Europeenne de Psychologie Appliquee, 67 (5), pp. 259-267.

Kim, T. and Gausdal, A.,H. (2017). Leading for safety: A weighted safety leadership model in shipping .Reliability Engineering\&System Safety, 165, pp. 458-466.

Kongsvik, T. O., Storkersen, K. V. and Antonsen, S. (2014). The relationship between regulation, safety management systems and safety culture in the maritime industry. In: $22^{\text {nd }}$ Annual Conference on European Safety and Reliability (ESREL), Amsterdam, Netherlands, 1013, pp. 467-473.

Lu, Ch., Hsu, Ch. and Lee, Ch. (2016). The Impact of Seafarers Perceptions of National Culture and Leadership on Safety Attitude and Safety Behaviour in Dry Bulk Shipping. International Journal of e-Navigation and maritime Economy, 4, pp: 75-87.

Pihowicz W. (2008). Inżynieria bezpieczeństwa technicznego (Technical Safety Engineering), WNT, Warszawa.

Rumawas, V. and Asbjornslett, B.E. (2016). Human factors on offshore supply vessels in the 
Norwegia Sea- an explanatory survey. Trans RINA. Intl J Maritime Eng, 158(A1).

Veiga, J.L. (2002). Safety Culture in Shipping. WMU Journal of Maritime Affairs, 1, pp. 17-31.

Wang, J. (2002). A brief review of marine and offshore safety assessment. Marine Technology and SNAME News, 39(2), pp. 77-85.

Date of submission of the article to the Editor: 06/2018

Date of acceptance of the article by the Editor: 09/2018 